\title{
A disequilibrium mechanism: When managerial decisions cause macroeconomic instability ${ }^{1}$
}

\author{
Mariusz Maziarz ${ }^{2}$
}

\begin{abstract}
The paper aims to develop our understanding of the processes and mechanisms leading to economic instability. The research design and methods: the paper employs a simple game-theoretic model aimed at depicting why the mechanism connecting nonmaterial motivation of managers and the propensity of economic systems is unstable. The findings are as follows: managers, driven by the nonmaterial value of work, choose strategies that maximize the likelihood of prolonging their employment. Shortsighted CEOs may prefer strategies that offer smooth returns and an unlikely "catastrophic event." If the unification of strategies occurs, the situation leads to a crisis and recession in the long run. The model put forth in this paper is shown to resemble the mechanism of the 2007-2008 financial crisis.
\end{abstract}

Keywords: disequilibrium mechanism, causes of recession, macroeconomic instability, mechanistic evidence, corporate governance, CEOs incentives.

JEL codes: B41, E32, E61, O43.

\section{Introduction}

The paper employs the methods of game theory with the aim of putting forth a model connecting managerial decisions to financial crises. The model offers an insight into the factors that shape inefficient managerial decisions and delivers a hint of why competing companies employ a similar strategy. The influence of CEOs' decisions on the global economic situation was raised after the dotcom bubble. The topic is also discussed in connection with the search for the mechanistic explanation of the 2007-2008 financial crisis (Benmelech, Kandel, \& Veroneri, 2010). The purpose of the paper is twofold. On the one hand, the analysis aims at advancing our understanding of why economies move out of their equilibrium states. On the other hand, it identifies the following gap in

\footnotetext{
${ }^{1}$ Article received 9 May 2018, accepted 15 December 2018.

${ }^{2}$ Institute for Market, Consumption, and Business Cycles Research-National Research Institute, Aleje Jerozolimskie 87, 02-001 Warszawa, Poland, mariusz.maziarz@ibrkk.pl / mariusz. mm@gmail.com.
} 
the literature: in macroeconomics, there is a limited number of explicitly causal, mechanistic analyses of the recessionary processes.

For this analysis, the realist stance in the philosophy of causality is accepted. Causal realism ${ }^{3}$ is the philosophical viewpoint according to which causal relations are distinct from other forms of relations (e.g. correlational) and independent from the researcher (Maziarz, 2017b). According to the stance employed for this analysis (known as the mechanistic theories of causality), to justifiably conclude that two variables or events are causally connected, the mechanisms that connect them should be understood and depicted. The causal mechanisms, as Little (1991, p. 15) put it, "are a sequence of events, conditions, and processes leading from the explanans to the explanandum." The epistemic methods of researching whether $\mathrm{X}$ causes $\mathrm{Y}$ ranges from the fallacious econometric tests, through experiments (becoming recently more popular in economics) and the randomized controlled trials (RCT) to the most reliable method of employing mechanical evidence (Maziarz, 2015). According to Glennan (2009), "[d]iscovering a mechanism is the gold standard for establishing and explaining causal connections.”

Understanding the mechanisms leading to the collapses and infecting other companies is a pressing issue. The recent global financial crisis resulted in the bankruptcy of several multinational financial corporations (Lehman Brothers being the most notable example) and nationalizing those believed to be too big to fail (Sorkin, 2010). The paper is structured as follows. In section 1, macroeconomic research focusing on recession is discussed. The reconstruction of post-crisis criticism of mainstream economics indicates that economists employ oversimplifying assumptions. One of such assumptions is the axiom of market equilibrium. In section 2, a simple model of a possible mechanism connecting suboptimal managerial decisions at the level of companies with macroeconomic instability is put forth. In section 4 , the model is shown to resemble the 2007-2008 financial crisis.

\section{Disequilibrium economics}

After the recent financial crisis, voices criticizing the mainstream economics for oversimplifications and unrealisticness occurred in the methodological debate (cf. Krugman, 2009; Colander et al., 2009; Mäki, 2017). Cline (2010) argued that the (false) assumption that markets are in equilibrium is the main problem of the discipline that constrains economic research. Soros (1994, p. 27) and Krugman (2009) highlighted that economics is the domain aimed at studying equilibrium. Krugman (2009) called it a "romanticized and sanitized vision of

\footnotetext{
${ }^{3}$ The stance in the ontology of causality should not be misunderstood as a semantic theory bearing the same name.
} 
the economy" (p. 2). Despite the emphasis put on the equilibrium state, a handful of theoretical analysis focusing on recessions can be listed. Considerable attention was put on describing transmission mechanisms (e.g. Borio \& Zhu, 2012) or proving that recessions can last (e.g. Böhm, 1978). However, virtually any analyzes are focusing on mechanisms snatching economies out of their equilibrium states (Aarle, 2017, p. 7). In summary, the post-crisis criticism of the mainstream economics accuses the discipline of focusing on equilibrium states and self-regulating markets. According to the abovementioned philosophers of economics and economists interested in the methodology of their discipline, economics oversimplifies the studied phenomena.

Even those economists that focus on theoretical studies of the disequilibrium aim at counteracting the effects of the mechanisms that lead to a recession (e.g. insufficient aggregate demand) instead of emphasizing understanding the causal factors. For example, Tamborini, Trautwein and Mazzocchi (2014) focused on equaling the investment-saving imbalances by means of monetary policy. Gebremeskel (2017) highlighted the role of lack of access to bank loans. Even the family of models called 'disequilibrium models' is limited in delivering detailed explanations of how the macroeconomic imbalances emerge. Büttler, Frei and Schips (2013, p. 1) indicated that the usual disequilibrium models could be divided into the following four groups: (1) the Walrasian demand and supply macroeconomic models, (2) microeconomic-foundation models, (3) implicit contracting models, and (4) econometric disequilibrium models. None of these models enlighten beyond highlighting the role of rigid prices and transaction costs. Contrary to the hitherto theoretical research, the mechanistic evidence of explicitly causal models is crucial for delivering the anti-crisis policy measures aimed at counteracting the causes of macroeconomic fluctuations instead of influencing the aggregate demand level after it was reduced by a causal mechanism (Grüne-Yanoff 2016; Maziarz 2017a).

\section{The disequilibrium mechanism}

In this section, a simple game theory model is offered with the aim of depicting the causal mechanism that makes economies internally unstable. The purpose is to offer an insight into why managerial decisions can be suboptimal and unified in their fallacy, and how the excessive risk-taking at the company level can cause macroeconomic instability. It is assumed that there are $N$ companies managed by managers. ${ }^{4}$ Each company $C_{N}$ is assumed to be managed in line with a safe strategy $S_{S}$ or a risky one $S_{R}$. The assumption that there are only two strategies

\footnotetext{
${ }^{4}$ The number of companies differs to a high extent depending on the type of market. However, monopolistic competition is the most popular type of market in the contemporary economy (cf. Porter, 1998).
} 
accessible to a market is certainly an approximation. In the real-world economy, one can distinguish as many strategies as the number of companies operating on a market (Kaynak \& Yavas, 1985; Chen, 1999). However, one can group the strategies undertaken by financial companies into the following two categories. First, some companies choose to profit from offering traditional banking services that are relatively low-risk behavior. Second, other companies prefer engaging in high-risk investment on financial markets (including derivatives markets). The distinction resembles the segmentation of the banking market put forth by the Glass-Steagall Act (cf. Kroszner \& Rajan, 1994). Therefore, the two-strategy axiom idealizes the situation of the current US banking sector divided into two types of financial activity. Considering a widely-known quote from Keynes' General theory stating that "[b] usiness men play a mixed game of skill and chance" (Mihályi, 2017, p. 11), profit $P_{t}$ is assumed to be a random variable characterized by memorylessness (i.e. the Markov property) ${ }^{5}$ and discrete time. For simplicity of the argument, exemplary values ${ }^{6}$ of the variables are delivered. The safe strategy $S_{S}$ is characterized by moderate levels of equiprobable profits and losses, and the positive math expectancy $E\left(S_{S}\right)=0,1$. Traditional banking (and other strategies idealized by the $S_{S}$ ) do not produce stable profits what is the result of economic fragility and interactions between heterogeneous agents (Gatti et al., 2005). Therefore, $S_{S}$ resembles the profit record of companies engaged in usual operations under normal market situation

$$
\begin{gathered}
S_{S}= \begin{cases}P_{t}=1,2 & p=0,5 \\
P_{t}=-1 & p=0,5\end{cases} \\
S_{R}=\left\{\begin{array}{cc}
P=1 & p=0,995 \\
P=-200 & p=0,005 .
\end{array}\right.
\end{gathered}
$$

The risky strategy $S_{R}$ is characterized by very likely profits and a very rare and huge loss resulting in bankruptcy. The 'catastrophic event' labeled also as 'black swan' (Taleb, 2007) makes companies lose all their previous profits. Therefore, companies managed in line with $S_{R}$ do not generate profit in the long run $E\left(S_{R}\right)=0$. Considering that $E\left(S_{S}\right)>E\left(S_{R}\right)$ and $\sigma\left(S_{S}\right)<\sigma\left(S_{R}\right)$, rational managers $M_{N}$ should prefer $S_{S}$ to $S_{R}$. Below, managers are shown to prefer $S_{R}$ under certain circumstances.

${ }^{5}$ In other words, profit earned by a company under consideration in year $T+1$ does not depend on either the previous year's profit $P_{t-1}$ or on any value from its historical record $P_{t-x}$.

${ }^{6}$ The numerical values were chosen with the aim at resembling basic statistics describing the American economy. The average long-term growth of companies equals approximately $10 \%$ (11,69\% between 1928 and 2007, strictly speaking (Damodaran, 2013). Financial institutions happen to lose approximately the sum of all their previous profits what proved the 1982 financial crisis (Mishkin, 1996; Taleb, 2010, p. 43). 
According to mainstream economics, companies are driven by the maximization of shareholder wealth (McWilliams \& Siegel, 2001; Jensen, 2002), i.e. maximization of profits $\sum_{1}^{t} P_{t}$ in this simplifying case. The role of moral hazard in the managerial decisions has been considered on the ground of agency theory (e.g. Eisenhardt, 1989). This analysis extends the hitherto literature by including the tacit (nonmaterial) factors motivating managers and showing how the actions of managers aimed at extending their contracts can cause the macroeconomic fluctuations. Considerable amount of literature focuses on evaluating CEO performance (Crawford et al., 1995; DeFond \& Park, 1999), the influence of CEO incentives (Zajac, 1990; Wang, 1997) and timing of dismissing CEO (Spear \& Wang, 2005) on company profits. Unfortunately, managers are usually assumed to maximize their personal income and the tacit factors are excluded from analysis. It is a realistic assumption that CEOs are also motivated by the tacit, nonmaterial factors (Kornai, 1992; Harris \& Helfat, 1997; Ugboro \& Obeng, 2000; Mihályi, 2017; Kałdoński \& Jewartowski, 2017).

Therefore, the utility function of managers $U_{M}$ depends on the nonmaterial value of work $(N V)$ and personal income $(P I): U_{M}=F(N V ; P I)$. CEO's income depends on an annual salary and company's profits and/or growth (Shin \& Seo, 2011). The top managers have a high level of job satisfaction (Scandura \& Lankau, 1997; Mihályi, 2017), and therefore the nonmaterial value of work (the utility delivered by working) is of considerable importance for the top-tier managers (cf. McClelland \& Burnham, 2008). Mihályi (2017, p. 9) disagreed with the outdated approach to the labor market according to which salary is a price for the negative utility connected to responsibilities and duties at a workplace. As he put it, "it is not true that work is a sacrifice for managers, which needs to be compensated with pay. The managerial work is itself a source of enjoyment, an activity which carries its own utility for the manager" (my emphasis). Considering that the work of a manager is pleasurable and satisfactory (even excluding the earnings), managers are motivated to undertake the decisions that will ensure them not to be discharged.

Since $F^{\prime}(P I)>0$ and $F^{\prime \prime}(P I)<0$ (Lindenberg, 1983; Smith, 1976), and considering the high level of CEO salary (Miller, 1995), the nonmaterial factors are likely to shape managerial decisions to a higher degree than maximizing personal income $F(\uparrow N V) \ggg F(\uparrow P I)$. Generally speaking, skilled workers (comparing to the unskilled labor force) appreciate their jobs to a degree higher than the value of their salary (Becker, 1994). In comparison, the jobs for unskilled workers usually demand intellectually undemanding, repetitive, and uninteresting duties that devoid employees of the possibility to fulfill oneself (Graeber, 2013; Glaser, 2014). Due to the fact that managers appreciate their jobs, one of the motivations is not to lose it. A job loss influences utility by reducing both $N V \downarrow$ and $P I \downarrow$. Therefore, $M_{N}$ are primarily motivated to undertake actions that will ensure prolonging their contracts instead of maximiz- 
ing personal income PI. There are two main reasons for dismissing a CEO: (1) the collapse of their company $C_{N}$ (Ang \& Chua, 1981) and recording poor results in a few consecutive years (Spear \& Wang, 2005; Fredrickson, Hambrick, \& Baumrin, 1988). ${ }^{7}$

Assuming that the disutility caused by being dismissed for company's underachievement $U_{1} \downarrow$ and the collapse caused by a catastrophic event $U_{2} \downarrow$ equals, ${ }^{8}$ a rational manager should aim at minimizing the likelihood of being dismissed. Considering Zhang's (2016) results, this prediction is empirically adequate. In the short term, considering limited responsibility managers think about likelihoods and not payoffs. Under these circumstances, it is more rational to prefer the nonoptimal strategy. Additionally, there is another reason for preferring the suboptimal strategy. Namely, the payoff matrices of the two strategies are not known to the investors both in the model and in the real-life situations. Stakeholders can only observe the historical record of profits and analyze contemporary strategic decisions undertaken by companies. However, the ability of investors to analyze the investment commitments is limited (Bala \& Madhavan, 2005; Froot, Scharfstein, \& Stein, 1992). Therefore, assuming that there are competing companies operating on the same market which economic activity, assets, and skills of their staff are similar, investors are likely to undertake their investment decisions considering past profits of the companies. ${ }^{9}$

There are some companies operating in a market and their shareholders compare their records of profit (for the importance of past revenues and profit on investors' decisions, see (Koller, Goedhart, \& Wessels, 2010). Benmelech et al. (2010, p. 1771) admitted that investors "do not observe investments but base their valuation only on dividend payouts". In this case, managers $\left(M_{1}, M_{2}, \ldots, M_{n}\right)$ aim at obtaining above-average or, at least, average results. Otherwise, a CEO managing a company that earns under-average returns can be discharged. Under the circumstances described above, the risky strategy $S_{R}$ minimizes the risk of dismissal. For instance, in a five-year period, the likelihood of bankruptcy for $S_{R}$ equals $\approx 0,025$. The likelihood of recording five consecutive years of loss for $S_{S}$ equals $\approx 0,031$. Recording losses when the competitors of the managed company are profitable is a serious ground for CEO's dismissal (Fredrickson et al., 1988). Additionally, the fact that people are more likely to accept a diminishable probability of a disastrous event than a considerably likely negative event (Taleb, 2010, p. 358) leads to the conclusion that it is psychologically easier for

\footnotetext{
${ }^{7}$ The decision is also shaped by the existence of new candidates and other factors. Therefore, more specific generalizations indicating when CEOs are discharged are not formulable.

${ }^{8}$ Considering "golden handshakes" received by dismissed CEOs, this assumption is an isolation of the influence of the separation pay. As Yermack (2006) reported, the fortune-500 companies pay approximately one-year salary to dismissed CEOs. On the other hand, the responsibility of managers is limited.

${ }^{9}$ See Grinblatt and Moskowitz's (2004) analysis for the influence of past returns on future profitability.
} 
managers to obey the risky strategy. In spite of the higher profitability of the safer strategy, due to Keynes' (1971, p. 65) observation that, "[i]n the long run we are all dead", the managers that are driven by such tacit factors as experiencing job satisfaction, prestige, power, and avoiding conflict instead of the neoclassical assumption of profit maximization, will, therefore, act according to the risky strategy. Finally, managers, in order to maximize PI (the second determinant of their utility), should stick to the more risky strategy $\left(S_{R}\right)$. In this case, both profits and the value of the managerial stock options will be, on average, higher than otherwise.

Above, the companies are shown to be likely to be managed in line with a unified strategy where a minimal risk of bankruptcy is preferred compared to a strategy yielding similar likelihoods of profits and losses and a positive return. In the case of the SOE (i.e. state-owned enterprises) whose managers, according to Mihályi (2017) were driven by similar factors as the people who manage free-market enterprises, the choice between the two strategies had not resulted in such severe consequences as in the case of the free-market corporations, ${ }^{10}$ because the socialist governments bailed out bankrupting companies.

The process of strategy unification proceeds as follows. (1) $\mathrm{N}$ companies are managed in line with $S_{S^{*}}(2)$ When one of the companies employs $S_{R}$ and records stable profits in a short term, its competitors acting according to $S_{S}$ seem to be mismanaged recording variable and lower profits. Considering that the pay-off matrices are not known to stakeholders in the real-life situations, the record of results of a company managed in line with $S_{R}$ is more attractive for investors (cf. Grinblatt and Moskowitz's analysis for the influence of past returns on stock-exchange performance, 2004). (3) $M_{N}$ that employed the more rational strategy $S_{S}$ are either dismissed for the under-average results or switch to $S_{R}$. Therefore, (4) the competition between $M_{N}$ will force them to choose the more risky $S_{R}$. Finally, $\mathrm{N}$ companies are governed according to $S_{R}$.

Eventually, the catastrophic event occurs and all companies on a considered market bankrupt. In the above-described thought experiment, the profits of each company were assumed to be independent, random variables. In this case, the likelihood of joint bankruptcy of all companies operating on a market could have been estimated using the copula method. However, in the realworld economy, the assumption of independent profits is not justified. In contrary, profits are correlated among companies and countries (cf. Antonakakis $\&$ Tondl, 2014). Some evidence suggests that in line with the prediction of the model put forth in this paper, the risk of bankruptcy is a systematic risk (Dichev,

${ }^{10}$ This passage should certainly not be read as an invitation to favoring the socialist economy or criticizing the market one. Considering that bankruptcies are driven by insufficient shortterm capital flows instead of long term profit, the difference is worth highlighting. Investigating the potential causes of disequilibria and recessions of the market economy is essential if Keynes' dream about stable economic growth and full employment (Sardoni, 2011, p. 2) is ever to be fulfilled. 
1998; Becchetti \& Sierra, 2003). The companies that employ similar strategies are usually exposed to similar risks. For example, all the financial institutions investing in the CDO market were exposed to the risk of house-prices fluctuations and the mortgage insolvency ratio. Therefore, the catastrophic event is likely to occur at the same time in several companies. Bankrupting companies fail at regulating their debts and dismiss their employees. Due to the reduced amount of disposable income, aggregate demand reduces, and, in line with the classical Keynesian analysis, a new equilibrium at a lower level of prices and output is established: $\downarrow A D \rightarrow \downarrow P \wedge \downarrow Y$. The influence of the collapsing companies on lower demand causing a recession was observed during the 2007-2008 crisis (Bricongne, Fontagné, Gaulier, Taglioni, \& Vicard, 2012; Homer-Dixon et al., 2015). Furthermore, bankrupting companies are likely to influence investors' risk aversion that lowers the supply of money. Such an event leads to a contractionary raise in interest rates.

\section{The model and the financial crisis}

The model put forth above indicates that, under certain circumstances, managers are likely to prefer the strategy that brings stable profits but also produces an unlikely and colossal loss leading to bankruptcy. The model resembles the mechanism that multiplied the effects of the American house-market bubble. The bubble is the widely accepted cause of the 2007-2008 financial crisis (Foster and Magdoff 2009, p. 35). However, its burst would not have such severe consequences for the world economy if banks and financial institutions based worldwide did not employ the strategy similar to $S_{R}$. The financial institutions, before the financial crisis, had been granting loans to people without documented incomes (the so called NINJA: no income, no job, no assets). Such mortgages were only backed with the houses (Acharya, Philippon, Richardson, \& Roubini, 2009), which value was believed to constantly trend upwards. The NINJA loans were collateralized. The CDO obligations were sold on the bond market. Additionally, the banks that invested in the CDOs usually hedged their investment with credit default swaps (CDS). In fact, investors betting that the housing market in the United States will decline could buy CDS. In the months preceding the outbreak of the crisis, the value of the market of CDSs exceeded the value of collateralized debt obligations what was one of the factors causing the problem with solvency. A number of financial institutions (e.g. AIG) was selling this derivative instrument (Stulz, 2010) what is, considering the payoff matrix, a strategy resembling $S_{R}$. However, they were saved from bankruptcy by government intervention (Shachmurove, 2011).

A few empirical analyses corroborate conclusions of the game-theoretic model delivered above. Fahlenbrach and Stulz (2011) analyzed banks' performance and their CEOs incentives during the recent financial crisis and con- 
cluded that the differences in the compatibility of their shareholders' and the managers' interests did not influence the profitability (or, to be more strict, the amount of loss caused by the bad debt) during the 2007-2008 financial crisis. The observation of the Swiss economists indicates that managers are indeed driven by factors others than PI, i.e. their salary and the value of managerial stock options. Pathan (2009) analyzed data from 212 large US bank companies and concluded that CEO power over bank boards positively correlates with excessive risk-taking what supports the conclusions that $M_{N}$ consider their limited responsibility in the decision-making process. However, Srivastav, Keasey, Mollah, and Vallascas (2017) observed that the post-crisis data shows that CEOs are punished for undertaking excessive risk what suggests that shareholders may be aware of the modeled mechanism and attempt at counteracting it.

Furthermore, Benmelech and others (2010) put forth a mechanistic model explaining the influence of monetary incentives on CEOs' decision to conceal negative information about a company's prospects for the future. Their analysis shows that CEOs that maximize their stock-based salary are willing not to publish negative information on the future of managed companies. In this way, according to their analysis, the lack of publically-accessible information drives a stock bubble: the assets are overvalued considering the actual chances for holding the hitherto pace of development. As the Quarterly Journal of Economics paper concludes, the institutional incentives to conceal negative news can be responsible for the last two American crises: the Hi-Tech boom and the 2007-2008 financial crisis. The model put forth in this paper sheds light on another mechanism: CEOs can maximize not their financial income exclusively but take into account also the nonmonetary value of work. In such a case, they can choose strategies that smooth a company profit but produce the risk of a catastrophic event. The financial institutions investing in the mortgage-based derivatives followed such a strategy. Benmelech and others' (2010) paper analyzed why the information on the falling growth opportunities (and incoming losses) were not published earlier. The model put forth here sheds light on the ground why the suboptimal strategy was followed.

\section{Conclusions}

Macroeconomy is a very complicated phenomenon, and there indeed are many mechanisms operating at the same time. The recent financial crisis proved that the mainstream economists' belief in self-regulating markets is not justified. The hitherto macroeconomic theory lacks models aimed at depicting internal mechanisms that cause disequilibria and recessions. Existing models do not go beyond indicating the role of rigid prices, insufficient aggregate demand caused by limited access to bank loans or external events in the case of the real business cycle theory. The purpose of this paper is to indicate that 
economic policy grounded in the hitherto disequilibrium models will only be able to counteract a crisis after its occurrence. To undertake preemptive measures, understanding the internal causal mechanisms (institutional factors that influence the process of decision making) that snatch economy out of its equilibrium state is essential. Therefore, the focus of the macroeconomists should move from analysis aiming at supply-demand inequality and focus on institutional and microeconomic factors that can potentially lead to severe macroeconomic inefficiencies.

The simple model put forth above resembles the mechanism that multiplied the effects of the American house-market bubble by extensive leveraging leading to smoothing profits in exchange for exposing companies to the catastrophic event. The mechanism shows that individual motivations and decisions can, under certain circumstances, create a disequilibrium mechanism that eventually causes a significant financial and economic crisis. In addition to indicating the gap in the hitherto theoretical literature, the game-theoretic model put forth above aims at taking sides in the methodological debate. On the one hand, the emphasis of theoretical macroeconomists should be put on producing explicitly causal models offering mechanistic evidence to raise the understanding of the nature of macroeconomic instability. On the other hand, models resembling the above-described one are implicitly grounded in microeconomic phenomena and therefore can be employed as an argument for the supervenience of macroeconomics on microeconomics.

\section{References}

Aarle, B. (2017). Macroeconomic fluctuations in a new Keynesian disequilibrium model. Journal of Economic Structures, 6(1), 10. doi: 10.1186/s40008-017-0070-2

Acharya, V., Philippon, T., Richardson, M., \& Roubini, N. (2009). The financial crisis of 2007-2009: Causes and remedies. Financial Markets, Institutions \& Instruments, 18(2), 89-137. doi: 10.1111/j.1468-0416.2009.00147_2.x

Ang, J. S., \& Chua, J. H. (1981). Corporate bankruptcy and job losses among top level managers. Financial Management, 10(5), 70-74. Retrieved from: http://www.jstor. org/stable/3664858?seq=1\#fndtn-page_scan_tab_contents

Antonakakis, N., \& Tondl, G. (2014). Does integration and economic policy coordination promote business cycle synchronization in the EU?. Empirica, 41(3), 541-575. doi: 10.1007/s10663-014-9254-2

Bala, M., \& Madhavan, S. (2005). Investors who are professionals are travelling by the same bus or not?. Accounting and Finance, 48(5), 719-739.

Becchetti, L., \& Sierra, J. (2003). Bankruptcy risk and productive efficiency in manufacturing firms. Journal of Banking \& Finance, 27(11), 2099-2120. doi: 10.1016/ S0378-4266(02)00319-9 
Becker, G. S. (1994). Human capital revisited. In G. S. Becker (Ed.), Human capital: A theoretical and empirical analysis with special reference to education (3rd ed., pp. 15-28). Chicago: University of Chicago Press.

Benmelech, E., Kandel, E., \& Veronesi, P. (2010). Stock-based compensation and CEO (dis) incentives. Quarterly Journal of Economics, 125(4), 1769-1820. doi: 10.1162/ qjec.2010.125.4.1769

Böhm, V. (1978). Disequilibrium dynamics in a simple macroeconomic model. Journal of Economic Theory, 17(2), 179-199.

Borio, C., \& Zhu, H. (2012). Capital regulation, risk-taking and monetary policy: A missing link in the transmission mechanism?. Journal of Financial Stability, 8(4), 236-251.

Bouissou, M. B., Laffont, J. J., \& Vuong, Q. H. (1986). Disequilibrium econometrics on micro data. Review of Economic Studies, 53(1), 113-124. doi: 10.2307/2297595

Bricongne, J. C., Fontagné, L., Gaulier, G., Taglioni, D., \& Vicard, V. (2012). Firms and the global crisis: French exports in the turmoil. Journal of International Economics, 87(1), 134-146. doi: 10.1016/j.jinteco.2011.07.002

Büttler, H. Frei, G. \& Schips, B. (2013). Estimation of disequilibrium models. Berlin: Springer Science \& Business Media.

Chen, T. Y. (1999). Critical success factors for various strategies in the banking industry. International Journal of Bank Marketing, 17(2), 83-92.

Cline, W. R. (2010). Financial globalization, economic growth, and the crisis of 20072009. Washington: Peterson Institute.

Colander, D., Goldberg, M., Haas, A., Juselius, K., Kirman, A., Lux, T., \& Sloth, B. (2009). The financial crisis and the systemic failure of the economics profession. Critical Review, 21(2-3), 249-267.

Crawford, A., Ezzel J., and Miles, J. (1995). Bank CEO pay-performance relations and the effects of deregulation. Journal of Business, 68(2), 231-256.

Damodaran, A. (2013). Equity risk premiums (ERP): Determinants, estimation and implications-The 2012 edition. In O. Roggi, E. Altman (Eds.), Managing and measuring risk: Emerging global standards and regulations after the financial crisis (pp. 343-455). World Scientific Series in Finance, vol. 5.

DeFond, M. L., \& Park, C. W. (1999). The effect of competition on CEO turnover. Journal of Accounting and Economics, 27(1), 35-56.

Dichev, I. D. (1998). Is the risk of bankruptcy a systematic risk?. Journal of Finance, 53(3), 1131-1147. doi: 10.1111/0022-1082.00046

Eisenhardt, K. M. (1989). Agency theory: An assessment and review. Academy of Management Review, 14(1), 57-74. doi: 10.5465/AMR.1989.4279003

Fahlenbrach, R., \& Stulz, R. M. (2011). Bank CEO incentives and the credit crisis. Journal of Financial Economics, 99(1), 11-26. doi: 10.1016/j.jfineco.2010.08.010

Foster, J. B., \& Magdoff, F. (2009). The great financial crisis: Causes and consequences. New York: New York University Press.

Fredrickson, J. W., Hambrick, D. C., \& Baumrin, S. (1988). A model of CEO dismissal. Academy of Management Review, 13(2), 255-270.

Froot, K. A., Scharfstein, D. S., \& Stein, J. C. (1992). Herd on the street: Informational inefficiencies in a market with short-term speculation. Journal of Finance, 47(4), 1461-1484. doi: 10.1111/j.1540-6261.1992.tb04665.x 
Gatti, D. D., Di Guilmi, C., Gaffeo, E., Giulioni, G., Gallegati, M., \& Palestrini, A. (2005). A new approach to business fluctuations: Heterogeneous interacting agents, scaling laws and financial fragility. Journal of Economic Behavior \& Organization, 56(4), 489-512. doi: 10.1016/j.jebo.2003.10.012

Gebremeskel, A. (2017). Income distribution and economic growth. In A. Heshmati (Ed.), Studies on economic development and growth in selected African countries (pp. 177-203). Singapore: Springer.

Giannetti, M. (2011). Serial CEO incentives and the structure of managerial contracts. Journal of Financial Intermediation, 20(4), 633-662. doi: 10.1016/j.jfi.2011.04.003

Glaser, E. (2014). Beyond bullshit jobs. Soundings, 57(57), 82-94. doi: $10.3898 / 136266214813474471$

Glennan, S. (2009). Mechanisms. In: H. Beebee (Ed.), The Oxford handbook of causation (pp. 315-325). Oxford: Oxford University Press.

Graeber, D. (2013). On the phenomenon of bullshit jobs: A work rant. Strike Magazine, (3), 1-5.

Grinblatt, M., \& Moskowitz, T. J. (2004). Predicting stock price movements from past returns: The role of consistency and tax-loss selling. Journal of Financial Economics, 71(3), 541-579. doi: 10.1016/S0304-405X(03)00176-4

Grüne-Yanoff, T. (2016). Why behavioural policy needs mechanistic evidence. Economics \& Philosophy, 32(3), 463-483.

Harris, D., \& Helfat, C. (1997). Specificity of CEO human capital and compensation. Strategic Management Journal, 18(11), 895-920.

Homer-Dixon, T., Walker, B., Biggs, R., Crépin, A. S., Folke, C., Lambin, E. F., ... \& Troell, M. (2015). Synchronous failure: The emerging causal architecture of global crisis. Ecology and Society, 20(3). doi: 10.5751/ES-07681-200306

Jensen, M. C. (2002). Value maximization, stakeholder theory, and the corporate objective function. Business Ethics Quarterly, 12(2), 235-256.

Kałdoński, M., \& Jewartowski, T. (2017). Agency costs of overvalued equity and earnings management in companies listed on WSE. Economics and Business Review, 3(1), 7-37. doi: 10.18559/ebr.2017.1.2

Kaynak, E., \& Yavas, U. (1985). Segmenting the banking market by account usage: An empirical investigation. Journal of Professional Services Marketing, 1(1-2), 177-188. doi: 10.1300/J090v01n01_19

Keynes, J. (1971). A tract on monetary reform. London: Macmillan.

Koller, T., Goedhart, M., \& Wessels, D. (2010). Valuation: Measuring and managing the value of companies (vol. 499). London: John Wiley and Sons.

Kornai, J. (1992). The postsocialist transition and the state: Reflections in the light of Hungarian fiscal problems. American Economic Review, 82(2), 1-21. Retrieved from: http://www.jstor.org/stable/2117368

Kroszner, R. S., \& Rajan, R. G. (1994). Is the Glass-Steagall Act justified? A study of the US experience with universal banking before 1933. American Economic Review, 84(4), 810-832.

Krugman, P. (2009). How did economists get it so wrong?. New York Times, 2(9), 2009. Retrieved from: www.nytimes.com/2009/09/06/magazine/06Economic-t.html

Lin, J. Y., \& Tan, G. (1999). Policy burdens, accountability, and the soft budget constraint. American Economic Review, 89(2), 426-431. doi: 10.1257/aer.89.2.426 
Lindenberg, S. (1983). Utility and morality. Kyklos, 36(3), 450-468.

Little, D. (1991). Varieties of social explanation: An introduction to the philosophy of social science. Boulder: Westview Press.

Mäki, U. (2017). Modelling failure. In H. Leitgeb, I. Niiniluoto, \& P. Seppala (Eds.). Logic, methodology and philosophy of science (Proceedings of the 15th international congress in Helsinki. London: College Publications. Retrieved from: https://pdfs. semanticscholar.org/5332/6e9790dc24be8d3597ec98b8a2fdda541bde.pdf

Maziarz, M. (2015). A review of the Granger-causality fallacy. Journal of Philosophical Economics: Reflections on Economic and Social Issues, 8(2), 86-105. Retrieved from: https://jpe.ro/pdf.php?id=7116

Maziarz, M. (2017a). The Reinhart-Rogoff controversy as an instance of the 'emerging contrary result' phenomenon. Journal of Economic Methodology, 24(3), 1-13. doi: 10.1080/1350178X.2017.1302598

Maziarz, M. (2017b). Przyczynowość w ekonomii. Najnowsze badania i nierozwiazane problemy. Annales. Ethics in Economic Life, 20(1), 63. doi: 10.18778/1899-2226.20.1.05

McClelland, D. C., \& Burnham, D. H. (2008). Power is the great motivator. Harvard, US: Harvard Business Review Press.

McWilliams, A., \& Siegel, D. (2001). Profit maximizing corporate social responsibility. Academy of Management Review, 26(4), 504-505.

Mihályi, P. (2017). The motivation of business leaders in socialist and market-based systems. Economics and Business Review, 3(17),100-111.

Miller, D. J. (1995). CEO salary increases may be rational after all: Referents and contracts in CEO pay. Academy of Management Journal, 38(5), 1361-1385.

Mishkin, F. S. (1996). Understanding financial crises: A developing country perspective (No. w5600 National Bureau of Economic Research). Retrieved from: https://www. nber.org/papers/w5600

Nassim, N. T. (2010). The black swan: The impact of the highly improbable. New York: Random House.

Pathan, S. (2009). Strong boards, CEO power and bank risk-taking. Journal of Banking \& Finance, 33(7), 1340-1350.

Porter, M. E. (1998). Clusters and the new economics of competition. Boston: Harvard Business Review.

Sardoni, C. (2011). Unemployment, recession and effective demand: The contributions of Marx, Keynes and Kalecki. Northampton: Edward Elgar Publishing.

Scandura, T. A., \& Lankau, M. J. (1997). Relationships of gender, family responsibility and flexible work hours to organizational commitment and job satisfaction. Journal of Organizational Behavior, 18(4), 377-391.

Shachmurove, Y. (2011). A historical overview of financial crises in the United States. Global Finance Journal, 22(3), 217-231. doi: 10.1016/j.gf.2011.10.012

Shin, J. Y., \& Seo, J. (2011). Less pay and more sensitivity? Institutional investor heterogeneity and CEO pay. Journal of Management, 37(6), 1719-1746. doi: $10.1177 / 0149206310372412$

Smith, V. L. (1976). Experimental economics: Induced value theory. American Economic Review, 66(2), 274-279.

Sorkin, A. R. (2010). Too big to fail: The inside story of how Wall Street and Washington fought to save the financial system--and themselves. New York: Penguin. 
Soros, G. (1994). The alchemy of finance: Reading the mind of the market. New York: John Wiley \& Sons.

Spear, S. E., \& Wang, C. (2005). When to fire a CEO: Optimal termination in dynamic contracts. Journal of Economic Theory, 120(2), 239-256.

Srivastav, A., Keasey, K., Mollah, S., \& Vallascas, F. (2017). CEO turnover in large banks: Does tail risk matter?. Journal of Accounting and Economics, 64(1), 37-55.

Stulz, R. M. (2010). Credit default swaps and the credit crisis. Journal of Economic Perspectives, 24(1), 73-92.

Sullivan, K., \& Kida, T. (1995). The effect of multiple reference points and prior gains and losses on managers' risky decision making. Organizational Behavior and Human Decision Processes, 64(1), 76-83. doi: 10.1006/obhd.1995.1091

Taleb, N. N. (2007). Black swans and the domains of statistics. American Statistician, 61(3), 198-200. doi: 10.1198/000313007X219996

Taleb, N. N. (2010). The black swan: The impact of the highly improbable. New York, USA: Random House.

Tamborini, R., Trautwein, H. M., \& Mazzocchi, R. (2014). Wicksell, Keynes, and the New Neoclassical Synthesis: What can we learn for monetary policy?. Economic Notes, 43(2), 79-114. doi: 10.1111/ecno.12016

Ugboro, I. O., \& Obeng, K. (2000). Top management leadership, employee empowerment, job satisfaction, and customer satisfaction in TQM organizations: An empirical study. Journal of Quality Management, 5(2), 247-272.

Wang, C. (1997). Incentives, CEO compensation, and shareholder wealth in a dynamic agency model. Journal of Economic Theory, 76(1), 72-105.

Yermack, D. (2006). Golden handshakes: Separation pay for retired and dismissed CEOs. Journal of Accounting and Economics, 41(3), 237-256.

Zajac, E. J. (1990). CEO selection, succession, compensation and firm performance: A theoretical integration and empirical analysis. Strategic Management Journal, 11(3), 217-230.

Zhang, X. (2016). Income Smoothing, Idiosyncratic Risk \& CEO Turnover. Journal of Mathematical Finance, 6(01), 1. 